\title{
FORECASTING THE EFFECTS OF A PLANNED RESERVOIR WHICH WILL PARTIALLY FLOOD THE TONGUE OF UNTERAARGLETSCHER IN SWITZERLAND
}

\author{
by \\ Martin Funk and Hans Röthlisberger
}

(Versuchsanstalt für Wasserbau, Hydrologie und Glaziologie, Eidegenössische Technische Hochschule, CH-8092 Zürich, Switzerland)

\begin{abstract}
In order to improve their hydro-electric power production in the Grimsel area, Kraftwerke Oberhasli (KWO) plan to construct a new reservoir with a storage level about $110 \mathrm{~m}$ higher than the existing Grimselsee. This paper deals with the expected changes of Unteraargletscher after periodical contact with the resulting water body. Upon initial flooding, the lowermost section of Unteraargletscher, about $800 \mathrm{~m}$ long, will float, drift away, and melt. A rough estimate of the heat balance shows that the energy input into the lake would be sufficient to melt this ice within 2-3 years, so that calving and melting will continue at a frontal ice cliff. The main effort of the study was aimed at forecasting this retreat. A pre-existing seismic survey was supplemented by new soundings by radar and seismic reflection, resulting in reliable cross-sections and information about the sub-bottom material. The forecast is based on the existing mass flux and an empirical calving rate relationship with water depth and predicts an equilibrium position of the terminus some $3-4 \mathrm{~km}$ further back than today, and a gain of water storage volume of $50 \times 10^{6} \mathrm{~m}^{3}$ after 10 years.
\end{abstract}

\section{INTRODUCTION}

KWO, a highly developed hydro-electric power scheme in central Switzerland, lacks storage space. A project referred to as Grimsel-West is being considered by the power company which would modify the Grimsel reservoir profoundly by constructing a second dam west of the existing one. This would raise the storage level by more than $100 \mathrm{~m}$. Preliminary glaciological studies showed that the terminus of Unteraargletscher would become flooded, that a major further retreat would follow, and an increase of storage volume would result, allowing for a smaller dam than was originally planned, with consequent savings. Subsequent glaciological investigations have served to indicate the optimum height of the dam.

\section{SITUATION}

Unteraargletscher is the name of the $6 \mathrm{~km}$ long flat ice tongue fed by a group of tributaries at the head of the River Aare. Glaciological research at Unteraar was initiated some 160 years ago and has been continued up to the present in numerous surveys and experiments (Haefeli, 1970; Haeberli, 1977; Iken and others, 1983). Some relevant data for our task was therefore readily available.

Figure 1 shows the outline of Unteraargletscher together with the location of the cross-sections numbered $1-10$ and the centre line with the zero point $(0)$ of the coordinate system, on which calculations and diagrams are based. The surface elevations and flow rates in sections 2, 7 , and 10, and also on the tributaries have been determined annually, mainly by Flotron and Flotron for KWO (Flotron, unpublished). Figure 2 shows the change in mean surface elevation since 1928, together with the average flow rate at the surface at profile 7 (Pavillon Dollfus). The elevation reflects a period of intensive glacier retreat during this century, although the rate of thinning of the tongue has diminished since 1965. In contrast with this, the surface elevation is still strongly decreasing at Obere Brandlamm (profile 2), but has remained practically unchanged since 1976 at Mieselenegg (profile 10). The velocity has, on average, not changed much since about 1950 at profiles 7 and 10 , whilst it is still decreasing steadily near the terminus. The latter trend shows that adjustment to the present-day climate is still actively in progress. Despite this, we consider Unteraargletscher to be close enough to equilibrium to be regarded as being in a state of equilibrium for the purposes of our study. As the standard year for the steady state we have chosen 1983-84.

Bed topograpy is as important as surface elevation and glacier flow for our investigation. Nye (1952) and Haefeli (1970) based some of their early computations of the flow of Unteraargletscher on seismic reflection soundings that were carried out from 1936 to 1950 . In our original analysis we used the same seismic data, taken from a detailed report by Knecht and Süsstrunk (unpublished). As the nature of the intermediate layer between an upper and lower seismic reflector was uncertain, we supplemented the

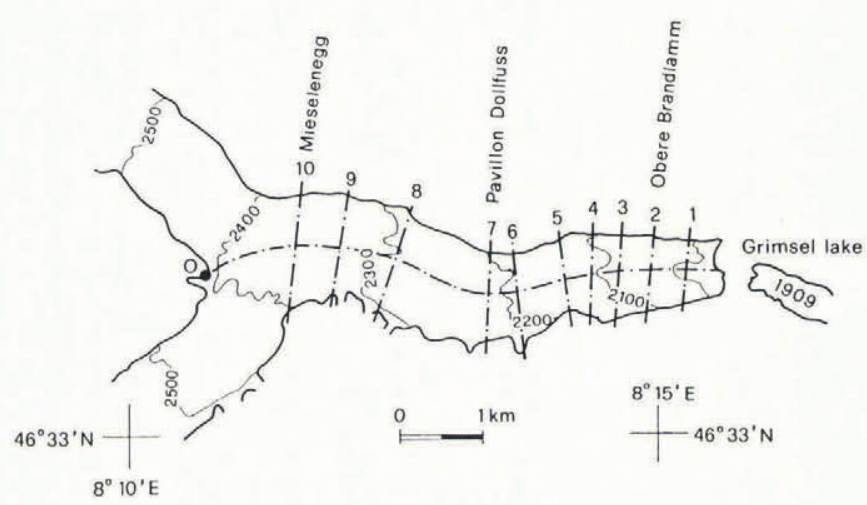

Fig. 1. Sketch map of Unteraargletscher; elevations in $\mathrm{m}$.

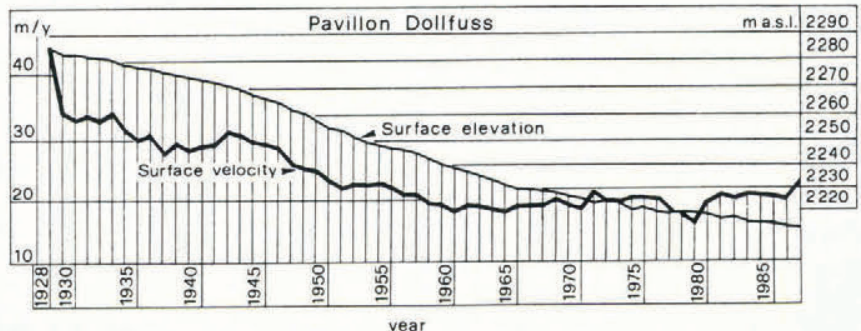

Fig. 2. Surface velocity and elevation over the tongue of Unteraargletscher, 1928-87. 


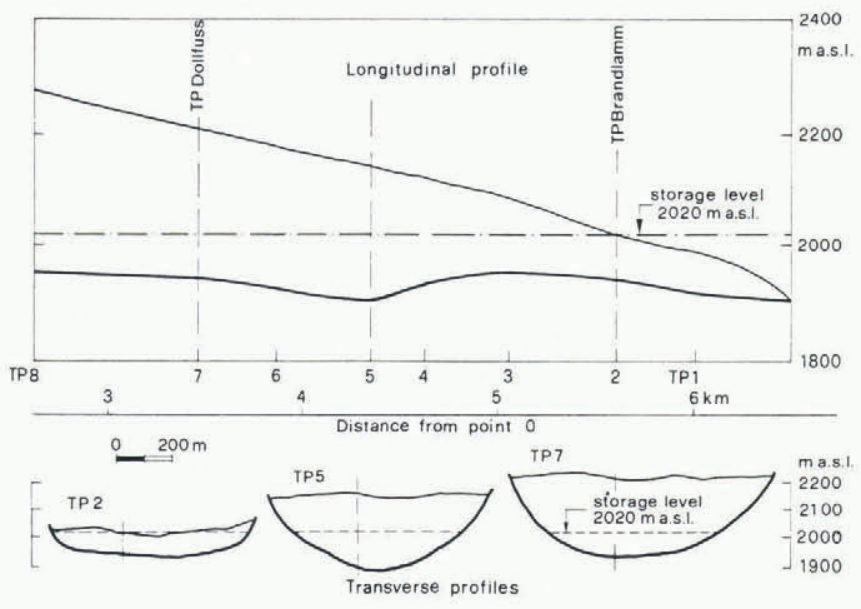

Fig. 3. Bed topography based on radio-echo soundings.

seismic soundings and finally replaced them by radio-echo soundings in cross-sections $1-8$, and along the centre line. The electromagnetic survey data matched the upper seismic survey reflector better than the lower one. A detailed seismic survey in the area of Obere Brandlamm showed that, at least in that area, the layer between the two seismic reflectors consisted of unconsolidated material with a low P-wave velocity of between 2.3 and $2.6 \mathrm{~km} \mathrm{~s}^{-1}$. The longitudinal profile and examples of transverse profiles are shown in Figure 3.

\section{CALVING SPEED IN LAKES}

Experience shows that the construction of a reservoir causes a pronounced retreat (or strongly accelerates a retreat already under way) of glaciers that terminate in the storage basin. This is because part of the energy absorbed by the lake causes ice to melt at the glacier terminus, where ice also breaks off. In view of the uncertainty about the nature of ice wastage for a glacier in contact with a water body, it would be preferable to have a neutral expression for the combined effect of true calving (mechanical separation of ice masses from the glacier) and subaqueous melting. Of the alternative expressions we have considered - aquatic, littoral, lake-front, lake-shore or coastline ablation, and their ablation rates - none seems completely satisfactory. We have therefore retained the more convenient term of calving rate for the total of ice loss at the glacier front.

A quantitative relationship between water storage and glacial retreat is needed for the purpose of forecasting retreat. Brown and others (1982) have established a linear relationship between calving speed and water depth for Alaskan tide-water glaciers. In Figure 4 we have plotted calving speed, $u_{\mathrm{c}}$, against water depth, $H_{\mathrm{w}}$, both averaged over the width of the glacier front, for six glaciers all terminating in lakes. Ideally, the calving speed, $u_{\mathrm{c}}$, is determined as follows:

$$
u_{\mathrm{c}}=u_{\mathrm{i}}+u_{\mathrm{r}}
$$

where $u_{\mathrm{i}}$ is the flow rate of the glacier at the front and $u_{\mathrm{r}}$ is the rate of retreat of the front (both averaged over the width of the glacier front). In some cases $u_{i}$ was measured on a transverse profile higher up the glacier rather than at the glacier front. In this case the following calculation was carried out:

$$
\left.\left.F_{\mathrm{i}}(\text { front })=F_{\mathrm{i}} \text { (profile }\right)-F_{\mathrm{b}} \text { (profile-front }\right)
$$

where $F_{\mathrm{i}}$ is the ice flux through respective cross-sections and $F_{\mathrm{b}}$ is the ice lost by ablation, $b$, at the surface area, $S$, between the transverse profile and the front. The flow rate, $u_{\mathrm{i}}$, of the glacier at the front is then

$$
u_{\mathrm{i}}(\text { front })=\frac{F_{\mathrm{i}(\text { front })}}{A_{\mathrm{c}}}
$$

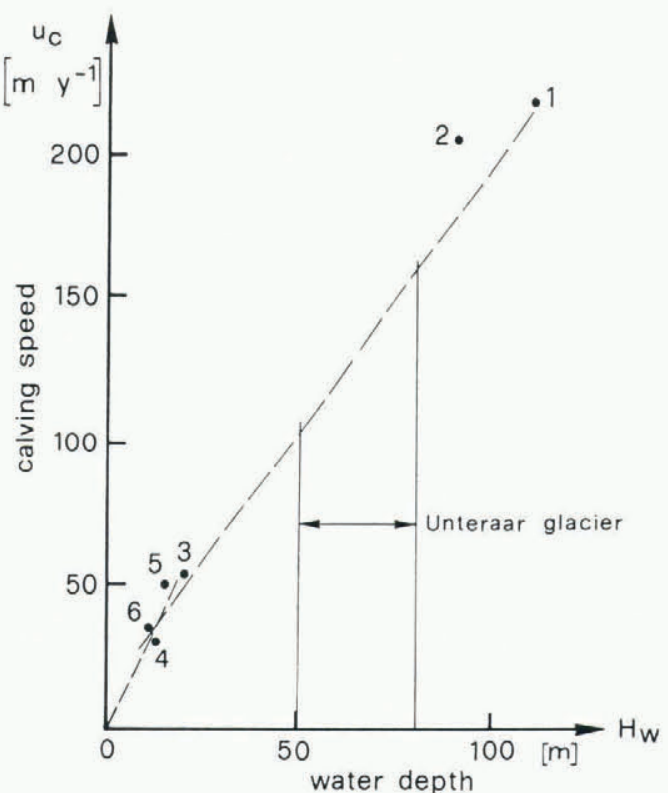

Fig. 4. Relationship between water depth, $H_{\mathrm{w}}$, and calving speed, $u_{\mathrm{c}}$, (see text for explanation).

where $A_{\mathrm{c}}$ is the cross-sectional area of the calving front. Numerical values are contained in Table I.

For the range of water depths between $40 \mathrm{~m}$ and $80 \mathrm{~m}$ expected to occur at Grimsel-West, the following equation expresses the empirical data:

$$
u_{\mathrm{c}}=1.9 H_{\mathrm{w}}+12
$$

where $H_{\mathrm{w}}$ is the mean water depth at the glacier front (in $\mathrm{m}$ ), and $u_{\mathrm{c}}$ is the mean calving speed (in $\mathrm{m} \mathrm{a}^{-1}$ ).

Some comments are needed on each of the six cases: (numbers refer to Table I and Figure 4).

(1) Portage, Alaska, $60^{\circ} 45^{\prime} \mathrm{N}, 30 \mathrm{~m}$ a.s.l.; bathymetric information, ice-surface elevation at the ice front, average recession rate for 1960-72 and surface velocity in summer 1972 about $2 \mathrm{~km}$ up-stream of the terminus all taken from Mayo and others (1982).

(2) Nordbo, south-west Greenland, $61^{\circ} 24^{\prime} \mathrm{N}, 660 \mathrm{~m}$ a.s.l.; ice flow into the lake was inferred from annual mass balance and ice-flux data from an area some $2-4 \mathrm{~km}$ up-stream of the terminus. The data point is unreliable because of both lack of data on the ice thickness and unproven assumptions about ablation rate, and hence the value of $F_{\mathrm{b}}$, in the highly crevassed terminal section of the glacier. Glaciological and bathymetric data were taken from Clement (1982, 1983).

(3) Sabbione, Italian Alps, $2466 \mathrm{~m}$ a.s.l.; detailed information on glacier retreat in a reservoir is available from topographic maps and diagrams; flow-rate value based on the assumption that the range of $H_{\mathrm{w}}=12-28 \mathrm{~m}$.

(4) Unteraar, Swiss Alps, $1909 \mathrm{~m}$ a.s.l.; detailed information

TABLE I. WATER DEPTH $\left(H_{\mathrm{W}}\right)$ : AVERAGED VELOCITIES OF ICE FLOW $\left(u_{\mathrm{i}}\right)$ : RETREAT $\left(u_{\mathrm{r}}\right)$ AND CALVING $\left(u_{\mathrm{c}}\right)$ OF GLACIERS ENDING IN FRESH-WATER LAKES; $H_{\mathrm{w}}$ IS AVERAGED OVER THE APPROPRIATE PERIODS FOR SITES 3 TO 6
Site

Season

\begin{tabular}{lrrrrr} 
Site & Season & $H_{\mathrm{w}}$ & \multicolumn{1}{c}{$u_{\mathrm{i}}$} & \multicolumn{1}{c}{$u_{\mathrm{r}}$} & $u_{\mathrm{c}}$ \\
& & $(\mathrm{m})$ & & $\left(\mathrm{m} \mathrm{a}^{-1}\right)$ & \\
& & & & & \\
1. Portage & $1971-72$ & 110 & 165 & 50 & 215 \\
2. Nordbo & $1979-80$ & 90 & 217 & -10 & 207 \\
3. Sabbione & $1961-73$ & 20 & 2 & 50 & 52 \\
4. Unteraar & $1932-45$ & 12 & 14 & 18 & 32 \\
5. Oberaar & $1953-67$ & 16 & 8 & 42 & 50 \\
6. Gries & $1968-79$ & 13 & 6 & 31 & 37
\end{tabular}

$u$

i

$\left(\mathrm{m} \mathrm{a}^{-1}\right)$ 
on retreat from the Grimsel reservoir and on ice flow close to the glacier terminus obtained from Flotron (unpublished); range of $H_{\mathrm{w}}=4-18 \mathrm{~m}$.

(5) Oberaar, Swiss Alps, $2303 \mathrm{~m}$ a.s.l.; detailed information on retreat in storage basin and on ice flow close to the terminus obtained from Flotron (unpublished); range of $H_{\mathrm{w}}=8-33 \mathrm{~m}$.

(6) Gries, Swiss Alps, $2386 \mathrm{~m}$ a.s.l.; detailed information on retreat in storage basin and on ice flow immediately behind the calving front taken from Siegenthaler (unpublished); range of $H_{\mathrm{w}}=10-16.5 \mathrm{~m}$. Bindschadler (1980) has shown that a linear dependency of calving flux on water depth is a good approximation for the observed retreat of the glacier retreat from 1967 to 1978 .

It is seen that the two cases (1) and (2) with deep water represent permanent lakes at high latitude, whereas the remaining cases (3) to (6) refer to Alpine reservoirs that are drained in winter and become gradually refilled in summer. The latter will also be the case at Unteraar, so that we could have extrapolated from the Alpine cases with shallow water to obtain the case for Unteraar. In Equation (4) we have instead used the direct connection from the centre of gravity of the Alpine cases to case (1), which is more reliable than case (2). By choosing a value for the calving speed that is on the low side (Fig. 4), we can be fairly confident that the increase of the storage volume with time will not be overestimated, and that in our forecast for the engineers we shall err on the side of safety.

We assume that the annual calving is low in cases (1) and (2) because of the high latitude. In a reservoir the period of calving is artificially shortened, but emptying and refilling may have an enhancing effect on calving. When the lake level drops, there is no longer any counter-pressure of water on the ice front which would lead to the collapse of the vertical ice wall. On the next refilling of the lake, broken-off ice fragments are floated away because of their buoyancy.

It is noteworthy that the calving rate determined by Brown and others (1982) for tide-water glaciers is many times larger than the rate found here for glaciers ending in fresh water. We suspect that density differences between the respective water bodies accounts for this, rather than the difference in water temperature. The buoyancy of $0^{\circ} \mathrm{C}$ melt water amounts to $132 \mathrm{~g} \mathrm{~m}^{-3}$ in fresh water at $4{ }^{\circ} \mathrm{C}$, but it is $26 \mathrm{~kg} \mathrm{~m}^{-3}$ in sea-water; thus there is a difference of a factor of 200 between buoyancy values. The buoyancy of $0^{\circ} \mathrm{C}$ melt water in silty fresh water would be even larger. Since the buoyancy of the $0^{\circ} \mathrm{C}$ film of melt water forming at the ice-water interface is probably one of the prime driving forces for the heat exchange (the glacier wind being another one), the suggested strong dependence of the calving rate on water density would indicate that melting at the ice front is of major importance. The density difference between fresh water and brine also affects water-pressure distribution at the ice front, hence an effect on true calving cannot be excluded. However, the buoyancy ratio for ice in fresh water and ice in brine amounts only to a ratio of $1.26: 1.00$, hardly sufficient to explain the different calving rates of fresh-water and tide-water glaciers. We are advised by $R$. Hooke (personal communication) that tidal action is another factor to be considered.

\section{EQUILIBRIUM POSITION OF GLACIER TERMINUS}

When Unteraargletscher becomes inundated, its lowermost section, about $800 \mathrm{~m}$ long, will float, drift away, and melt, whereupon calving will continue at a frontal ice cliff. As the terminus retreats further, at a rate depending on water depth, the amount of ice removed from a given cross-section increases with increasing ice thickness and with increasing rate of ice flow in this same cross-section. We assume the glacier to be in a stationary state, so that ice flux is originally independent of time. Because of the lower elevation of the top of the ice cliff as compared with the original glacier surface, ice flow will temporarily increase until a new equilibrium is established. The ice flux will then return to a value somewhat less than the original one, the reduction in which will be diminished by an amount accounted for by an increase in ablation in the section of the tongue where the ice surface has become significantly lower and where the ablation rate may have further increased by the effect of crevassing. By neglecting these effects, we assume that in equilibrium the ice flux at the new terminus is the same as it was originally at the same location in the undisturbed glacier. The ice flux in simple terms is expressed by

$$
F_{\mathrm{i}}=A_{\mathrm{i}} u_{\mathrm{i}}
$$

where $A_{\mathrm{i}}$ is the area of cross-section obtained by the radioecho soundings at cross-section $i$, and $u_{i}$ is the average flow rate, taken to be equal to the Flotron measurements of mean surface velocity.

The calving flux, $F_{\mathrm{c}}$, is

$$
F_{\mathrm{c}}=u_{\mathrm{c}} A_{\mathrm{c}}
$$

where $A_{\mathrm{c}}$ is the cross-sectional area of calving front, and $u_{\mathrm{c}}$ is the calving speed. To determine $A_{\mathrm{c}}$, we have relied upon experience with similar cases which has led to the assumption of a frontal height of $30 \mathrm{~m}$ a.s.l. $A_{\mathrm{c}}$ is calculated by adding this height to the cross-section below water level, determined from the radio-echo data, plus and the height of the proposed dam. Table II gives $A_{\mathrm{i}}, A_{\mathrm{c}}, u_{\mathrm{i}}, u_{\mathrm{c}}, H_{\mathrm{w}}, F_{\mathrm{i}}$, and $F_{\mathrm{c}}$ values for the cross-sections examined.

In Figure $5, F_{\mathrm{c}}$ and $F_{\mathrm{i}}$ are given as functions of the location. At the point of intersection of the two curves, where ice flux balances loss, the calving front will reach its

TABLE II. AREAS OF CROSS-SECTION $\left(A_{\mathrm{i}}, A_{\mathrm{C}}\right)$; WATER DEPTH $\left(H_{\mathrm{w}}\right)$; FLOW RATE $\left(u_{\mathrm{i}}\right)$; CALVING RATE $\left(u_{\mathrm{c}}\right)$; CALVING FLUX $\left(F_{\mathrm{c}}\right)$; AND ICE FLUX $\left(F_{\mathrm{i}}\right)$ FOR

\begin{tabular}{|c|c|c|c|c|c|c|c|}
\hline PS & $A_{\mathrm{i}}$ & $A_{\mathrm{c}}$ & $\begin{array}{l}H_{\mathrm{w}} \\
(\mathrm{m})\end{array}$ & $\begin{array}{l}u_{\mathrm{i}} \\
\quad(\mathrm{r}\end{array}$ & $\left.{ }^{-1}\right)$ & $\begin{array}{l}F_{\mathrm{c}} \\
\left(\times 10^{6}\right.\end{array}$ & $\left(a^{-1}\right)$ \\
\hline 3 & 0.0928 & 0.0619 & 57 & 10 & 120 & 7.4 & 0.9 \\
\hline 4 & 0.1103 & 0.0586 & 63 & 17 & 132 & 7.7 & 1.8 \\
\hline 5 & 0.1394 & 0.0689 & 82 & 18 & 168 & 11.6 & 2.5 \\
\hline 6 & 0.1545 & 0.0516 & 59 & 19 & 124 & 6.4 & 2.9 \\
\hline 7 & 0.1858 & 0.0526 & 54 & 20 & 115 & 6.0 & 3.7 \\
\hline 8 & 0.2599 & 0.0526 & 51 & 27 & 109 & 5.7 & 7.0 \\
\hline
\end{tabular}
PROFILE SECTIONS EXAMINED (PS)

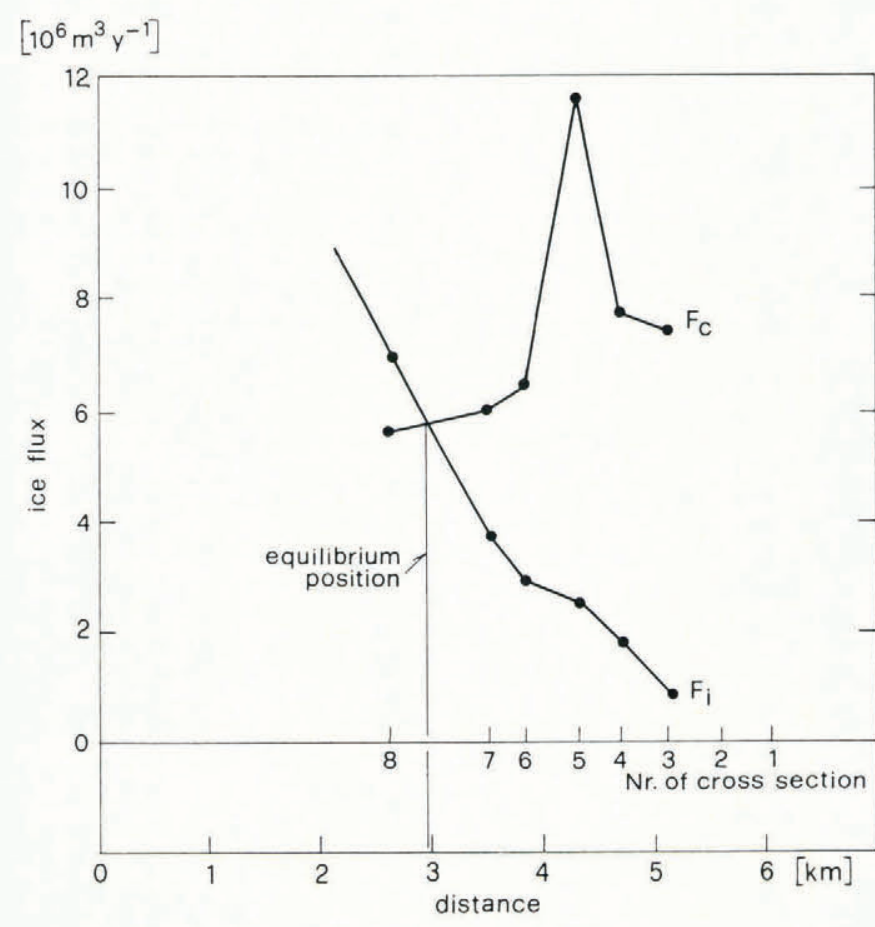

Fig. 5. Calving flux, $F_{\mathrm{C}}$, and ice flux, $F_{\mathrm{i}}$, as functions of distance (in $\mathrm{km}$ ) from point $\mathrm{O}$ on Unteraargletscher (cf. Fig. 1). 


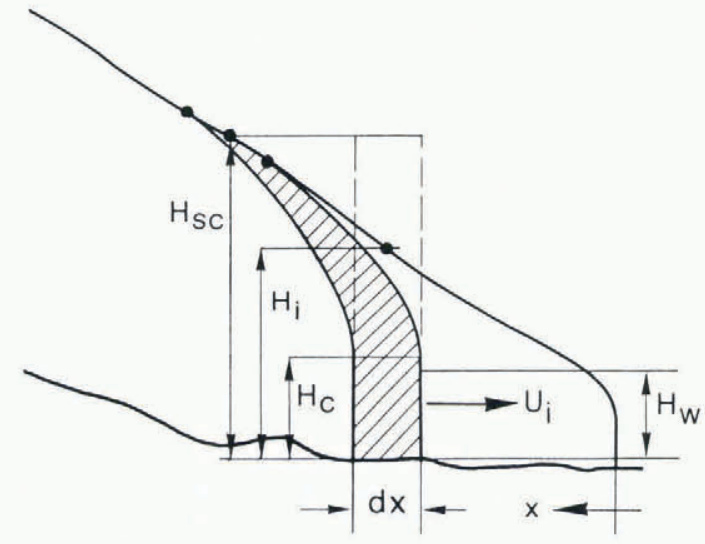

Fig. 6. Schematic representation of glacier retreat caused by calving.

equilibrium position. Similar curves have been constructed for a number of different storage levels. Since the level of $2020 \mathrm{~m}$ was found to be most appropriate to the needs of the project, results are given here for that level only. The spectacular peak in the $F$ curve reflects the overdeepening of the bed at cross-section 5 (Fig. 3) and the resulting increase in $A_{\mathrm{c}}$ (Table II).

\section{PROGRESS WITH TIME OF THE GLACIER RETREAT}

Figure 6 illustrates the retreat of a glacier as the result of its contact with a lake. For each value of thickness or depth, $H$, there exists a corresponding cross-section, $A$. The amount of ice lost by calving per unit time, $A_{\mathrm{c}} u_{\mathrm{c}}$, must equal the original ice flux, $A_{\mathrm{i}} u_{\mathrm{i}}$, plus an increment due to the retreat of the front, $A_{\mathrm{sc}} \mathrm{d} x$, thus

$$
A_{\mathrm{c}} u_{\mathrm{c}} \mathrm{d} t=A_{\mathrm{i}} u_{\mathrm{i}} \mathrm{d} t+A_{\mathrm{sc}} \mathrm{d} x
$$

where $A_{\mathrm{SC}}$ is the cross-section of glacier at the point where the original glacier profile and the new one meet. From glaciers up to about $300 \mathrm{~m}$ thick, showing an undisturbed flat surface some $0.5-1 \mathrm{~km}$ up-stream of an ice fall, we expect the surface lowering behind the calving front to occur over a similar range of $0.5-1 \mathrm{~km}$.

The rate of retreat, $u_{\mathrm{r}}$, is then

$$
u_{\mathrm{r}}=\frac{\mathrm{d} x}{\mathrm{~d} t}=\frac{u_{\mathrm{c}} A_{\mathrm{c}}-u_{\mathrm{i}} A_{\mathrm{i}}}{A_{\mathrm{Sc}}} .
$$

Considering the other uncertainties in our computations and also that part of the ice on the side walls of the valley will probably melt there rather than move into the lake, we have used $A_{\mathrm{i}}$ instead of $A_{\mathrm{SC}}$ in our calculations. For the first 10 years of retreat, the difference between the results with $A_{\mathrm{i}}$ and $A_{\mathrm{Sc}}$ was found to be small.

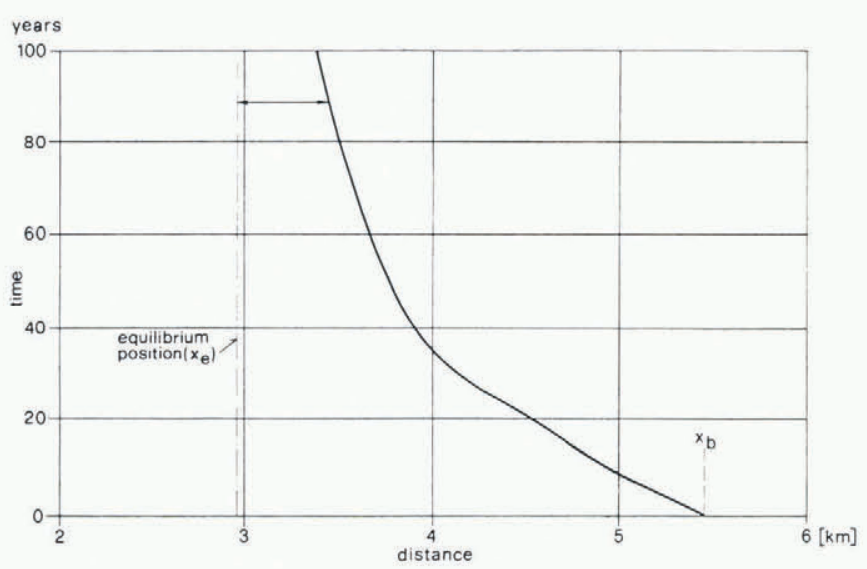

Fig. 7. Duration of retreat of glacier front after beginning of calving process, as a function of distance (in $\mathrm{km}$ ) from point $\mathrm{O}$ (cf. Fig. 1).
Retreat as a function of time from the start of the calving process (position $x_{\mathrm{b}}$ ) until equilibrium (position $x_{\mathrm{e}}$ ) is defined by

$$
t_{x_{\mathrm{b}} x_{\mathrm{e}}}=\int_{x_{\mathrm{b}}}^{x_{\mathrm{e}}} \frac{1}{u_{\mathrm{r}}(x)} \mathrm{d} x .
$$

This equation has been solved numerically and the results are shown in Figure 7.

The volume of the reservoir increases when the glacier retreats, and this increase can be derived as a function of time from the beginning of the calving process. Figure 8 shows the result for the first 10 years.

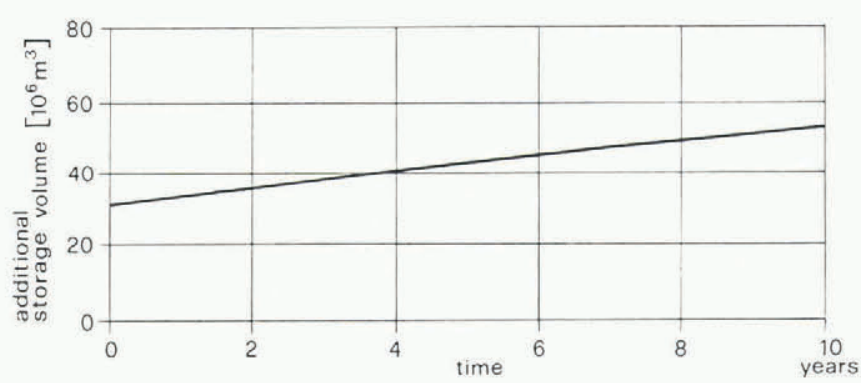

Fig. 8. Increase of reservoir volume as a function of time after beginning of calving process.

\section{ASSESSMENT OF MELTING CAPACITY OF LAKE}

In the process of gradual flooding of Grimsel Lake up to an elevation of $2020 \mathrm{~m}$ a.s.1., the lowermost part of Unteraargletscher, measuring approximately $800 \mathrm{~m}$ in length and having an ice volume of approximately $36 \times 10^{6} \mathrm{~m}^{3}$, will float. When this ice mass has melted away, after the first complete filling of the lake, calving at the glacier front will continue and the glacier will retreat in accordance with the calculations above. In this section of the paper the melting capacity of the lake will be assessed, on the basis of the energy balance at the surface, in order to examine whether the energy budget of the lake could be a limiting factor in the retreat of the glacier. We assume that all of the energy absorbed by the lake is available for melting glacier ice. The energy exchanged, $Q_{\mathrm{T}}$, at the water surface per unit area is given by

$$
Q_{\mathrm{T}}=Q_{\mathrm{R}}+Q_{\mathrm{H}}+Q_{\mathrm{L}}
$$

where $Q_{\mathrm{R}}$ is the radiation budget; $Q_{\mathrm{H}}$ is the detectable heat flux, and $Q_{\mathrm{L}}$ is the latent heat flux. The calculation of these energy fluxes was carried out for the months of July, August, and September, using in one case a year with average weather conditions and in another a year with extremely unfavourable weather conditions. The radiation budget, $Q_{\mathrm{R}}$, at the lake surface is defined as

$$
Q_{\mathrm{R}}=G(1-a)+A-E
$$

where $G$ is the global short wave radiation influx; $a$ is the albedo, and $A$ and $E$ the incoming and outgoing long-wave radiation. Data on $G$ and $A-E$ for an elevation of $2000 \mathrm{~m}$ a.s.l. were taken from a study by Sauberer and Dirmhirn (1952).

Cloud conditions for an average year and for an unfavourable year are taken into account, and the albedo, $a$, of the lake surface is estimated to be $8 \%$ (personal communication from A. Ohmura). The detectable heat flux, $Q_{\mathrm{H}}$, represents heat exchange by convection. It is expressed as follows

$$
Q_{\mathrm{H}}=f c_{\mathrm{p}}\left(T_{\mathrm{a}}-T_{\mathrm{s}}\right)
$$


TABLE III. ENERGY BUDGET AT LAKE SURFACE FROM JULY TO SEPTEMBER: FOR AN AVERAGE YEAR (SUBSCRIPT $\mathrm{n}$ ), FOR AN EXTREMELY UNFAVOURABLE YEAR (SUBSCRIPT e)

\begin{tabular}{|c|c|c|c|c|c|c|c|}
\hline Month & $\begin{array}{r}Q_{\mathrm{R}, \mathrm{n}} \\
(\mathrm{MJ}\end{array}$ & $\begin{array}{l}Q_{\mathrm{R}, \mathrm{e}} \\
\left.\mathrm{d}^{-1}\right)\end{array}$ & $Q_{\mathrm{H}, \mathrm{n}}$ & $Q_{\mathrm{H}, \mathrm{e}}$ & $Q_{\mathrm{L}, \mathrm{n}}$ & $Q_{\mathrm{L}, \mathrm{e}}$ & $Q_{\mathrm{T}, \mathrm{n}}$ \\
\hline 7 & 20.4 & 13.1 & 4.5 & 2.3 & 1.2 & -1.8 & 26.1 \\
\hline 8 & 16.6 & 10.7 & 4.8 & 2.4 & 1.9 & -1.8 & 23.3 \\
\hline 9 & 12.8 & 7.7 & 3.9 & 1.5 & 0.0 & -2.6 & 16.7 \\
\hline
\end{tabular}

where $c_{\mathrm{p}_{1}}$ is the the specific heat of dry air $\left(1.005 \mathrm{~J} \mathrm{~kg}^{-1} \mathrm{~K}^{-1}\right), T_{\mathrm{a}}$ is the air temperature; $T_{\mathrm{S}}$ is the lake surface temperature; $f$ is the heat transfer coefficient (a function of wind speed, $u$ ). Data for $T_{\mathrm{a}}$ and $u$ at the Grimsel Hospiz station were taken from Annalen der Schweizerischen Meteorologischen Anstalt. Mean values for a 12 year period and values for 1977, an extremely unfavourable year, were used, and a lake-surface temperature of $2^{\circ} \mathrm{C}$ was assumed for the calculation of $Q_{\mathrm{H}}$. The latent heat flux, $Q_{\mathrm{L}}$, is defined as

$$
Q_{\mathrm{L}}=f^{\prime} L\left(e_{\mathrm{a}}-e_{\mathrm{S}}\right)
$$

where $e_{\mathrm{a}}$ is the water-vapour pressure of the surrounding air; $e_{S}$ is the water-vapour pressure of the air at the lake surface; $L$ is the the latent heat of evaporation $\left(2.5 \times 10^{6} \mathrm{~J} \mathrm{~kg}^{-1}\right)$; and $f^{\prime}$ is the heat-transfer coefficient. Data on the relative humidity at the Grimsel Hospiz station were again drawn from Annalen der Schweizerischen Meteorologischen Anstalt; using these and $T_{\mathrm{a}}$ values, it was possible to determine values for $e_{\mathrm{S}}$ and then for $e_{\mathrm{a}}$. For the calculation of $Q_{\mathrm{L}}$, it has been assumed that surface air is always saturated with water. The figures for the energy budget at the lake surface for the months of July to September are summarized in Table III.

In order to include in the calculation all of the energy absorbed by the lake, the temporal variation of the lake surface area must be considered. The surface area of the lake is known to increase as the lake fills up, and on completion of the dam the lake will be filled to levels increasing from year to year to reach $2020 \mathrm{~m}$ a.s.l. in the fifth year. For our purposes only the two last years are relevant, and in these the lake surface will rise from $1980 \mathrm{~m}$ a.s.1. to $2020 \mathrm{~m}$ a.s.l. At $1980 \mathrm{~m}$ a.s.1., an estimated $10 \times 10^{6} \mathrm{~m}^{3}$ of ice will float, and at $2020 \mathrm{~m}$ a.s.1. the remaining $26 \times 10^{6} \mathrm{~m}^{3}$ of ice will follow. The energy exchanged through the lake surface has been calculated for the fourth, fifth, and sixth years of filling, taking into account these variations in the lake surface area. With the assumption that the additional energy is completely available for melting, and using a value for latent heat of melting of $3.3 \times 10^{8} \mathrm{~J} \mathrm{~m}^{-3}$, the potential melt volumes for the 3 years were calculated (Table IV). It can be seen that the estimated energy intake during this period is more than sufficient to melt the $36 \times 10^{6} \mathrm{~m}^{3}$ of ice expected to be afloat in the fourth to the sixth years after completion of the dam, provided that the atmospheric conditions do not deviate very much from average. The low value of $26 \times 10^{6} \mathrm{~m}^{3}$ is based on the unlikely situation of extremely unfavourable weather conditions for three consecutive years. It can be concluded that the initial phase, when large volumes of ice are afloat after the flooding of the terminal section of the tongue, will delay by no more than 1 or 2

TABLE IV. ESTIMATES OF ICE VOLUMES LIKELY TO BE MELTED IN GRIMSEL-WEST LAKE. UNDER AVERAGE (SUBSCRIPT n), AND UNDER UNFAVOURABLE (SUBSCRIPT e), WEATHER CONDITIONS

$\begin{array}{ccccc}V_{4, \mathrm{n}} \quad V_{4, \mathrm{e}} & V_{5, \mathrm{n}} \quad V_{5, \mathrm{e}} & V_{6, \mathrm{n}} V_{6, \mathrm{e}} & \Sigma_{\mathrm{n}} \quad \Sigma_{\mathrm{e}} \\ \left(\times 10^{6} \mathrm{~m}^{3}\right) & \left(\times 10^{6} \mathrm{~m}^{3}\right) & \left(\times 10^{6} \mathrm{~m}^{3}\right) & \left(\times 10^{6} \mathrm{~m}^{3}\right)\end{array}$

$\begin{array}{llllllll}15 & 7 & 18 & 9 & 20 & 10 & 53 & 26\end{array}$

years the normal process of retreat by calving. Note that, for such normal retreat the computed calving flux, $F_{\mathrm{c}}$, in Table II is considerably smaller than the annual melting capacity of the lake. The energy intake of the lake, therefore, does not seem to be a limiting factor after the initial phase.

\section{OUTLOOK}

The time available for the investigations described in this paper was limited, and it was clear from the beginning that the results would need to be re-examined later. When doing this, a high priority should be given to the collection of further experimental data on calving rates in deep water, especially where possible for lakes with periodic drainage. Data on the influence of water temperature and turbidity on density should also be collected, the mechanism of calving and in particular of the relative importance of melting as against true mechanical calving should be thoroughly studied. In order to predict the development of the ice-surface profile, existing conditions above ice falls should be further assessed for variations in ice thickness and flow rate so that more empirical data will be available. Further empirical data are needed for the assessment of albedo for turbid lakes in the context of the heat-balance question. In addition to this, theoretical solutions of this three-dimensional problem should be attempted.

With reference to the environmental impact, our work has also touched upon the questions of calving waves and surge probability, but these have not been included in this discussion. It has been shown that even at high surge speeds the displacement of water would not be likely to cause catastrophic run-off; calving waves, however, should be scrutinized more closely in the future.

The study was required to provide reasonably firm answers within a short time. Many assumptions had therefore to be made because the time available did not allow a thorough investigation. This may be typical of applied work related to human activities where quick answers are always sought. By revealing areas of lack of knowledge, such studies stimulate future research.

\section{ACKNOWLEDGEMENTS}

We thank M. Aellen, Dr A. Iken, and $\mathrm{Dr}$ W. Haeberli for many helpful discussions. Thanks are due to A. Zryd who assisted in the field work. We are greatly indebted to the Kraftwerke Oberhasli AG, especially to Director F. Benelli, for their interest in this study and for permission to publish it. S. and $\mathrm{Dr}$ L. Braun helped with the English text. The authors wish to thank the referees, in particular Dr R. Hooke, who reviewed the first draft and helped to improve it substantially.

\section{REFERENCES}

Annalen der Schweizerischen Meteorologischen Anstalt. [Annals of the Schweizerische Meteorologische Anstalt.] Bindschadler, R. The predicted behavior of Greigsletscher, Wallis, Switzerland, and its possible threat to a nearby dam. Z. Gletscherkd. Glazialgeol., 16(1), 45-59. 
Brown, C.S., M.F. Meier, and A. Post. 1982. Calving speed of Alaska tidewater glaciers, with application to Columbia Glacier. U.S. Geol. Surv. Prof. Pap. 1258-C.

Clement, P. 1982. Glaciologiske undersøgelser i Johan Dahl Land, Sydgrønland, 1981. Gronl. Geol. Undersøgelse. Gletscher-Hydrol. Medd. 82/1.

Clement, P. 1983. Glaciologiske Undersøgelser i Johan Dahl Land 1982. Gronl. Geol. Undersøgelser. Gletscher-Hydrol. Medd. $83 / 1$.

Flotron, A. 1932-1985. Unpublished. Berichte über die Ergebnisse der Gletschermessungen im Auftrag der Kraftewerke Oberhasli.

Haeberli, W. 1977. Experience with glacier calving and air-bubbling in high Alpine reservoirs. J. Glaciol., 19(81), 589-594.

Haefeli, R. 1970. Changes in the behaviour of the Unteraargletscher in the last 125 years. J. Glaciol., 9(56), 195-212.

Iken, A,, H. Röthlisberger, A. Flotron, and W. Haeberli.
1983. The uplift of Unteraargletscher at the beginning of the melt season - a consequence of water storage at the bed? J. Glaciol., 29(101), 28-47.

Knecht, H. and A. Süsstrunk. 1952. Unpublished. Die seismischen Untersuchungen auf dem Unteraargletscher 1936-1950. Bericht im Auftrag der schweizerischen Gletscherkommision.

Mayo, L.R., C. Zenone, and D.C. Trabant. 1977. Reconnaissance hydrology of Portage Glacier. Alaska 1972. U.S. Geological Survey. Hydrol. Invest. Atlas.

Nye, J.F. 1952. A comparison between the theoretical and the measured long profile of Unteraar Glacier. J. Glaciol., 2(12), 103-107.

Sauberer, F. and I. Dirmhirn. 1952. Der Strahlungshaushalt horizontaler Gletscherflächen auf dem hohen Sonnblick. Geogr. Ann., 34(3-4), 261-290.

Siegenthaler, H. 1968-1979. Unpublished. Berichte über die Hydrologie und Glaziologie des Griesseegebietes im Auftrag der Kraftwerke Aegina AG. 